\title{
Involvement of Cholesterol Membrane Transporter Niemann-Pick C1-Like 1 in the Intestinal Absorption of Lutein
}

\author{
Yuki Sato ${ }^{1}$, Risa Suzuki ${ }^{1}$, Masaki Kobayashi ${ }^{1}$, Shirou Itagaki ${ }^{1}{ }^{1}$,a , Takeshi Hirano ${ }^{1,{ }^{\dagger}}$, Toshihiro Noda ${ }^{1}$, Satoshi Mizuno $^{2}$, \\ Mitsuru Sugawara ${ }^{1,}$ Ken $_{\text {Iseki }}{ }^{1}$ \\ ${ }^{1}$ Division of Pharmasciences, Faculty of Pharmaceutical Sciences, Hokkaido University. Kita-12, Nishi-6, Kita-ku, \\ Sapporo, Japan. \\ ${ }^{2}$ JARD Inc. 2-7, 4-Chome, Nishi-Ochiai, Shinjuku-ku, Tokyo, Japan.
}

Received, February 13, 2012; Accepted, Feb 24, 2012; Published, April 9, 2012.

\begin{abstract}
PURPOSE. Lutein is a carotenoid mainly found in green leafy vegetables and is located in the macula lutea in the human eye. Since humans cannot synthesize lutein de novo, it must be digested as food. The physiological importance of an orally administered compound depends on its interaction with target tissues. It is therefore important to clarify the absorption mechanism in the intestine. Cholesterol membrane transporters Niemann-Pick C1 Like 1 (NPC1L1) and scavenger receptor class B type 1 (SR-B1) are involved in the intestinal absorption of highly lipophilic compounds including cholesterol. Ezetimibe, a selective inhibitor of intestinal NPC1L1, is the widespread lipid-lowering agent. It is important to investigate the possibility of food-drug interactions in order to prevent undesirable and harmful clinical consequences. The aim of this work was to determine whether NPC1L1, SR-B1 and other transporters are involved in absorption of lutein. METHODS. Caco-2 cells were used for accumulation and permeability study of lutein. Lutein concentration was determined by an HPLC system. The cDNA of transporters was isolated from total RNA of Caco-2 cells, and the expression of these transporters was confirmed by RT-PCR (reverse transcription - polymerase chain reaction). RESULTS. Ezetimibe inhibited up to $40 \%$ of lutein accumulation by Caco-2 cell monolayers. Block lipid transport 1 (BLT-1), a selective chemical inhibitor of SR-B1, also inhibited lutein accumulation by Caco-2 cells. On the other hand, ATP-depletion reagents (sodium fluoride and sodium azide or carbonyl cyanide m-chlorophenylhydrazone) did not influence the accumulation or permeation of lutein significantly. CONCLUSIONS. The results show that lutein absorption is, at least in part, mediated by influx transporters NPC1L1 and SR-B1 rather than mediated by efflux transporters such as ABC (ATP-binding cassette) transporters.
\end{abstract}

This article is open to POST-PUBLICATION REVIEW. Registered readers (see "For Readers") may comment by clicking on ABSTRACT on the issue's contents page.

\section{INTRODUCTION}

Lutein is a major carotenoid that is present in dark green leafy vegetables such as spinach and kale and in various fruits $(1,2)$. Chemically, lutein differs from other carotenoids. It has two hydroxyl groups, one on each side of the molecule. Thus, it is referred to as a xanthophyll (3). In the human eyes, lutein is a macular pigment that is located in the macula lutea, yellow spots, between incoming photons and photoreceptors (4). Lutein has been thought to provide protection to the photoreceptors as blue light filters and powerful antioxidants (5). Macular pigment density has been reported to correlate with plasma concentrations and dietary intake of lutein $(6,7)$. It has been reported that high serum carotenoid level and high dietary intake of lutein are associated with lower relative risk of age-related macular degeneration (AMD) (8). AMD is a leading cause of irreversible blindness in the elderly in developed countries in the western world, and the incidence of AMD has been increasing in

\footnotetext{
†a Present affiliation: Department of Pharmacy, Hirosaki University Hospital, Hirosaki, Japan. 53, Hon-cho, Hirosaki 036-8563, Japan; ${ }^{\dagger \mathrm{b}}$ Present affiliation: Department of Pharmacy, Kobe University Hospital, Kobe, Japan. 5-2, 7-Chome, Kusunoki-cho, Chuo-ku, Kobe 650-0017, Japan.

Corresponding Author: Ken Iseki, Ph. D., Laboratory of Clinical Pharmaceutics \& Therapeutics, Division of Pharmasciences, Faculty of Pharmaceutical Sciences, Hokkaido University Kita-12-jo, Nishi-6-chome, Kita-ku, Sapporo, Japan, E-mail: ken-i@pharm.hokudai.ac.jp
} 
Asia recently $(9,10)$. The pathogenesis of AMD is not completely understood; however, there is a growing body of evidence suggesting that oxidative stress, particularly that caused by reactive oxygen species (ROS), plays an important role. It has also been reported that lutein suppressed the translocation of nuclear factor (NF)- $\mathrm{kB}$ p65 and showed an anti-inflammatory effect (11). This is consistent with the hypothesis that lutein prevents AMD.

Although the effect of lutein has received much attention recently due to its antioxidant activities, there is little detailed information about the absorption mechanism of lutein. Reboul et al. reported that the transport of lutein partly involved scavenger receptor class B type 1 (SR-B1) (12). SR-B1 is a protein originally described as an HDL (high-density lipoprotein) receptor mediating the selective uptake of cholesteryl ester from HDL particles (13). SR-B1 is indeed expressed on the apical surface of enterocytes $(14,15)$. Raldula et al. reported that the uptake of HDL particles was inhibited by BLT-1 (block lipid transport-1), which is a selective inhibitor of SR-B1 (16). In addition to HDL particles, SR-B1 is also involved in vitamin E transport across enterocytes (17). However, the uptake of these highly lipophilic substances is not completely inhibited by BLT-1 $(12,17)$. Intestinal absorption of these substances is thought to be an integrated process.

In 2004, Niemann-Pick C1-Like 1 (NPC1L1) was shown to play an essential role in intestinal cholesterol absorption (18). Discovery of NPC1L1 has greatly enhanced the understanding of whole-body cholesterol absorption and specifically intestinal cholesterol absorption, a process that can be blocked by the selective cholesterol inhibitor ezetimibe (19). In a clinical setting, ezetimibe (Zetia ${ }^{\circledR}$, Schering-Plough Corp.) is a widely used medicine for hyperlipidemia. NPC1L1 is highly expressed in the small intestine, particularly in the upper intestine $(18,20)$. It has a predicted sterol-sensing domain (SSD), and the substrates of NPC1L1 have sterol domains and have been mainly thought to transport the substance involving the sterol structure. However, fat-soluble nutrients such as vitamin $\mathrm{E}$ that do not have a sterol structure are transported by NPC1L1 (21). As stated above, the absorption mechanism of these compounds is not completely understood. We hypothesized that NPC1L1 would be a good candidate for determining the absorption mechanism of lutein. If so, in patients with hyperlipidemia who take ezetimibe, there might be little effect of lutein for prevention of AMD. It is important to investigate the possibility of interactions between foods and drugs in order to prevent undesirable and harmful clinical consequences. In the current study, we investigated whether NPC1L1 is involved in the intestinal lutein accumulation.

\section{MATERIALS AND METHODS}

\section{Chemicals}

The emulsion formulation of lutein was kindly supplied by JARD Inc. (Tokyo, Japan) and Koyo Mercantile Co., Ltd. (Kyoto, Japan). Ezetimibe, (4-fluorophenyl)-(3R)-[3-(4-fluorophenyl)-(3S)-hy droxypropyl]-4S-(4-hydroxyphenyl)-2-azetidinone was purchased from Sequoia Research Products Ltd. (Pangbroune, UK). BLT-1 (Block lipid transport-1), 2-hexy-1-cyclopentanone thiosemicarbazone, was purchased from ChemBridge (San Diego, CA). BLT-1 was dissolved in $100 \%$ DMSO (dimethyl sulfoxide) to form a $10 \mathrm{mM}$ solution as described previously (22). All other reagents were of the highest grade available and used without further purification.

\section{Cell culture}

Caco-2 cells obtained from RIKEN (Ibaraki, Japan) were maintained in plastic culture flasks (Corning Costar Inc., NY) as described previously (23). The medium used for growth of Caco-2 cells was Dulbecco's modified Eagle's medium (Sigma, St. Louis, MO) with $10 \%$ fetal bovine serum (ICN Biomedicals Inc., Aurora, $\mathrm{OH}), 1 \%$ non-essential amino acids (Gibco-Invitrogen, Carlsbad, CA), 4 $\mathrm{mM}$ glutamine (Invitrogen, Grand Island, NY) and $100 \quad \mathrm{IU} / \mathrm{ml}$ penicillin-100 $\mu \mathrm{g} / \mathrm{ml}$ streptomycin (Sigma, St. Louis, MO). Monolayer cultures were grown in an atmosphere of $5 \% \mathrm{CO}_{2} / 95 \%$ air at $37^{\circ} \mathrm{C}$. The cells were given fresh growth medium every 2 days. When the cells had reached confluence after 4-6 days in culture, they were harvested with $0.25 \mathrm{mM}$ trypsin and $0.2 \%$ EDTA (about $5 \mathrm{~min}$ at $37^{\circ} \mathrm{C}$ ), resuspended, and seeded into a new flask. Cells between the $38^{\text {th }}$ and $55^{\text {th }}$ passages were used in this study.

\section{Uptake study in Caco-2 cell monolayers}

For uptake study, Caco- 2 cells were seeded at a cell density of 1.0-2.0 $\times 10^{5}$ cells/well on a 12-well plastic plate (Corning Costar Inc., NY). The cell 
monolayers were given a fresh medium every 2 days and were used at 4-6 days for the uptake experiments.

The incubation buffer used for the uptake study was HBSS (Hank's balanced salt saline)-HEPES ((pH 7.4) buffer (25 mM D-glucose, $137 \mathrm{mM} \mathrm{NaCl}$, $5.37 \mathrm{mM} \mathrm{KCl}, 0.3 \mathrm{mM} \mathrm{Na}_{2} \mathrm{PO}_{4}, 0.44 \mathrm{mM} \mathrm{KH}_{2} \mathrm{PO}_{4}$, $1.26 \mathrm{mM} \mathrm{CaCl}_{2}, 0.8 \mathrm{mM} \mathrm{MgSO}_{4}$ and $10 \mathrm{mM}$ HEPES, pH 7.4 adjusted with $1 \mathrm{M}$ Tris). After removal of the medium, $1.0 \mathrm{ml}$ of incubation buffer containing a substrate was added. The monolayers were incubated for the indicated time at 37 or $4{ }^{\circ} \mathrm{C}$. Each cell monolayer was rapidly washed twice with $1.0 \mathrm{ml}$ ice-cold incubation medium at the end of the incubation period. The cells were then solubilized with $0.25 \mathrm{ml}$ of $1 \mathrm{M} \mathrm{NaOH}$ and neutralized with $0.25 \mathrm{ml}$ of $1 \mathrm{M} \mathrm{HCl}$. The samples were kept at $-80^{\circ} \mathrm{C}$ until assay.

\section{Transport study}

For transport study, Caco-2 cells were seeded at a cell density of 1.0-2.0 $\times 10^{5}$ cells/well on a 12-well (3 $\mu \mathrm{m}$ pores, $1.0 \mathrm{~cm}^{2}$ growth area) transwell (Corning Costar Inc., NY). The procedure was carried out as described in a previous report (24) with some modification. The cell monolayers were given a fresh medium every 2 days and were used at 16-21 days for the transport experiments. TEER (transepithelial electrical resistance) was used to monitor the integrity of the monolayers. Monolayers with TEER above $300 \Omega \mathrm{cm}^{2}$ were used for the transport study. TEER values were calculated by the following equation:

TEER $=\{$ resistance value $(\mathrm{W})-$ blank value $(\mathrm{W})\} \times$ surface area $\left(\mathrm{cm}^{2}\right)$.

The incubation buffer was the same as that described above (uptake study in Caco-2 cell monolayers). After removal of the growth medium from both sides of the monolayers, the cells were preincubated at $37^{\circ} \mathrm{C}$ for $10 \mathrm{~min}$ with HBSS-HEPES buffer (12 wells; $0.5 \mathrm{ml}$ of apical side and $1.5 \mathrm{ml}$ of basal side). The incubation buffer containing lutein was added in a side after removal of the incubation buffer. The monolayers were incubated for $60 \mathrm{~min}$ at $37^{\circ} \mathrm{C}$. For transport measurements, samples were collected for immediate analysis. The apparent permeability coefficient $\left(P_{a p p}\right)$ was calculated using the following equation:

$$
P_{a p p}=d Q / d t \times 1 /\left(A \times C_{0}\right),
$$

where $d Q / d t$ is the linear appearance rate of mass in the receiver solution, $A$ is the filter/cell area (1.0 $\mathrm{cm}^{2}$ ), and $C_{0}$ is the initial concentration of lutein $(35 \mu \mathrm{M})$.

Kinetic parameters were obtained using the following equation:

$$
v=\mathrm{V}_{\max } \times \mathrm{s}\left(\mathrm{K}_{\mathrm{m}}+\mathrm{s}\right)+\mathrm{K}_{\mathrm{ns}} \times \mathrm{s},
$$

where $v$ is the uptake rate of the compound, $\mathrm{s}$ is the compound concentration in the buffer, $\mathrm{K}_{\mathrm{m}}$ is the Michaelis-Menten constant and $V_{\max }$ is the maximam uptake rate. $K_{n s}$ represents non-saturable uptake clearance.

\section{Analytical procedure}

The concentration of lutein was determined using an HPLC system as described previously (25). The column was a GL Science Inertsil CN-3 $(5 \mu \mathrm{m}$ in particle size, $4.6 \mathrm{~mm}$ in inside diameter $\times 250 \mathrm{~mm}$ ). A mobile phase containing hexane /dichloromethane/methanol/N-ethyldiisopropylami ne $=750 / 250 / 4 / 1 \quad(\mathrm{v} / \mathrm{v} / \mathrm{v} / \mathrm{v}) \quad$ was used. Column temperature and flow rate were $30^{\circ} \mathrm{C}$ and 1.5 $\mathrm{ml} / \mathrm{min}$, respectively. The wavelength for detection of lutein was $444 \mathrm{~nm}$. Protein was measured by the method of Lowry et al. with bovine serum albumin as a standard (26).

\section{RT-PCR analysis}

RT-PCR (reverse transcription polymerase chain reaction) was performed as described previously (27). Total RNA was prepared from Caco-2 cells using an ISOGEN (Nippon Gene, Tokyo, Japan) and an RNase-Free DNase Set (QIAGEN). Single-strand cDNA was made from $1 \mu \mathrm{g}$ total RNA by reverse transcription using a Rever Tra Ace (TOYOBO, Osaka, Japan). PCR was performed using Hot Star Taq DNA polymerase (QIAGEN) through 40 cycles of $95^{\circ} \mathrm{C}$ for $15 \mathrm{~s}$, $60^{\circ} \mathrm{C}$ for $15 \mathrm{~s}$ and $72^{\circ} \mathrm{C}$ for $30 \mathrm{~s}$ with human(h) NPC1L1-specific primers, hSR-B1-specific primers and GAPDH (glyceraldehyde 3-phosphate dehydrogenase)-specific primers. The primers specific to hNPC1L1, SR-B1 and GAPDH were designed on the basis of sequences in GenBank ${ }^{\mathrm{TM}}$ database (accession \#: NM_001101648, BC022087 and NM_002046, respectively). The sequences of the specific primers were as follows: the sense sequence “ '5'-ATG AGT CCC AAG GTG ACG 
AC-3' " and the antisense sequence " 5'-GTG ACC ACA GCG AAG ACA GA-3" " were for hNPC1L1, the sense sequence " 5'-CTG TGG GTG AGA TCA TGT GG-3" " and the antisense sequence " 5'-GCC AGA AGT CAA CCT TGC TC-3' " were for hSR-B1, and the sense sequence " 5'-AAG GTC ATC CCT GAG CTG AA-3 "' and the antisense sequence “ 5'-TTC TAG ACG GCA GGT CAG GT-3' " were for hGAPDH. The PCR products were subjected to electrophoresis on a $2 \%$ agarose gel and then visualized by ethidium bromide staining with UV light. Image processing was performed with ATTO image Saver AE-6905.

\section{STATISTICAL ANALYSIS}

Student's $t$ test was used to determine the significance of differences between two groups' means. Statistical significance among means of more than two groups was determined by one-way analysis of variance (ANOVA). Statistical significance was defined as $\mathrm{p}<0.05$.

\section{RESULTS}

\section{Accumulation of lutein and effect of temperature on lutein accumulation by Caco-2 cells}

In the first part of study, accumulation of lutein by Caco-2 cells was measured. The time course of lutein accumulation is shown in Figure 1. The accumulation of lutein linearly increased for $60 \mathrm{~min}$ after the start of incubation. Thus, the initial accumulation was evaluated for $60 \mathrm{~min}$. We then investigated the effect of temperature on the accumulation of lutein for up to $60 \mathrm{~min}$ by Caco-2 cells (Figure 2). The accumulation of lutein at $4^{\circ} \mathrm{C}$ was reduced compared with that at $37^{\circ} \mathrm{C}$. Temperature effect does not necessarily imply transporters.

Concentration dependence of lutein accumulation by Caco- 2 cells

Next, we investigated the concentration -dependence of lutein accumulation by Caco-2 cells (Figure 3). We confirmed that accumulation of lutein increased in a dose-dependent manner up to about $100 \mu \mathrm{M}$. The apparent $\mathrm{K}_{\mathrm{m}}$ and $\mathrm{V}_{\max }$ values were calculated to be $78.0 \pm 13.1 \mu \mathrm{M}$ and 0.85 $\mathrm{nmol} / \mathrm{mg}$ protein $/ 60 \mathrm{~min}$, respectively. These results suggested that lutein accumulation in Caco- 2 cells involved some active processes. Lutein concentration was therefore set at $35 \mu \mathrm{M}$ after this study from the point of the limit quantification (10 $\mu \mathrm{M})$.

\section{Direction of transport of lutein across Caco-2 cell monolayers}

Next, we investigated the direction of lutein across Caco-2 cell monolayers using a Transwell plate (Table 1). There was a tendency for permeation from the apical side to basal side across the Caco-2 monolayers to be greater than that from the basal side to apical side. The results suggested that influx transporters contributed to the intestinal absorption of lutein rather than efflux transporters. To ensure that cells were not damaged, particularly when micelles were added to the basolateral medium, the integrity of the monolayers was checked by measuring TEER after experiments during preliminary tests (data not shown).

\begin{tabular}{|c|c|}
\hline Direction & $\begin{array}{l}\text { Apparent permeability coefficient }\left(\mathrm{P}_{\mathrm{app}}: \mathrm{x}\right. \\
\left.10^{6} \mathrm{~cm} / \mathrm{sec}\right)\end{array}$ \\
\hline A to $\mathrm{B}$ & $4.95 \pm 1.14$ \\
\hline $\mathrm{B}$ to $\mathrm{A}$ & $2.07 \pm 0.216$ \\
\hline \multicolumn{2}{|c|}{$\begin{array}{l}\text { The permeation of lutein across the Caco- } 2 \text { cell membrane was } \\
\text { measured at } \mathrm{pH} 7.4 \text { at } 37^{\circ} \mathrm{C} \text {. Each value represents the mean } \pm \\
\text { S.D. of } 3-4 \text { measurements. }\end{array}$} \\
\hline
\end{tabular}

\section{Influx transporters expressed in Caco-2 cells}

To investigate influx transporters involved in lutein accumulation by Caco-2 cells, mRNA expression of NPC1L1 and SR-B1 was confirmed by RT-PCR analysis. As shown in Figure 4, RT-PCR analysis clearly demonstrated mRNA expression of NPC1L1 and SR-B1 in Caco-2 cells.

\section{Effect of selective inhibitors of the transporters on lutein accumulation by Caco- 2 cells}

We then investigated the effect of ezetimibe, which is a selective inhibitor of NPC1L1, on the lutein accumulation by Caco-2 cells (Figure 5-A).

Lutein accumulation was significantly inhibited in a concentration-dependent manner by ezetimibe at concentration s up to $40 \mu \mathrm{M}$ compared with the effect of $0 \mu \mathrm{M}$ of ezetimibe (control). At $40 \mu \mathrm{M}$ of ezetimibe, lutein accumulation was decreased by $40 \%$. Lutein accumulation by Caco- 2 cells was also significantly inhibited by BLT-1, which is a selective inhibitor of SR-B1 (Figure 5-B). 


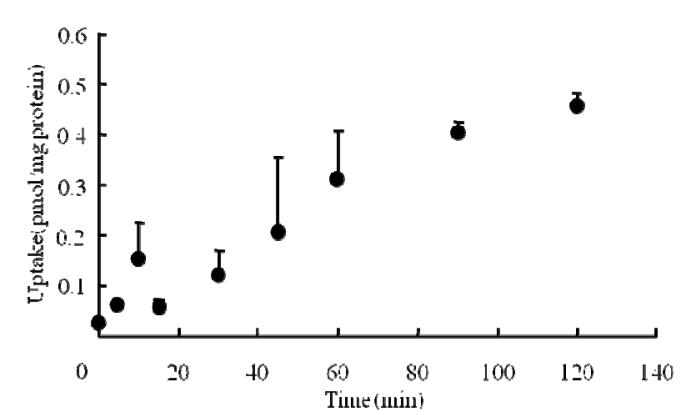

Figure 1. Time course of lutein accumulation by Caco-2 cells. The uptake of lutein $(35 \mu \mathrm{M})$ was measured at $\mathrm{pH}$ 7.4 at $37^{\circ} \mathrm{C}$. The concentration of lutein was determined using an HPLC system. Each point represents the mean with S.D. of 3-9 measurements.

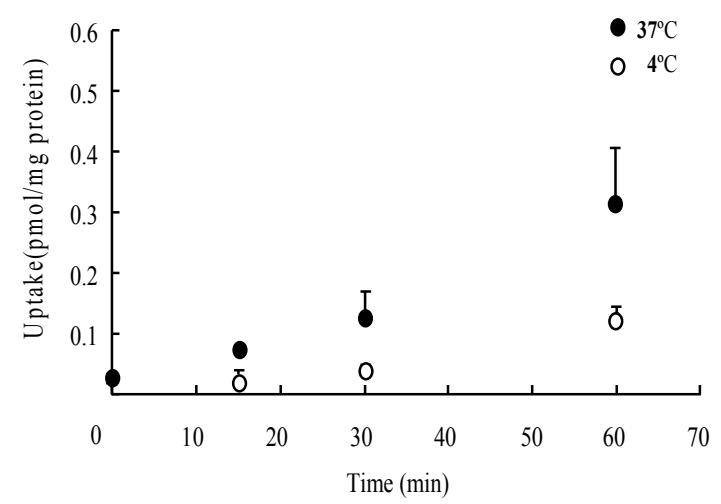

Figure 2. Effect of temperature on accumulation of lutein in Caco-2 cells. The buffer was preincubated at $37^{\circ} \mathrm{C}$ for $10 \mathrm{~min}$ in the presence of $10 \mathrm{mM}$ sodium fluoride and $10 \mathrm{mM}$ sodium azide or $50 \mu \mathrm{M} \mathrm{CCCP}$ or HBSS (control). And the accumulation of lutein in the presence of these inhibitors was investigated. The uptake of lutein $(35 \mu \mathrm{M})$ was measured at $\mathrm{pH} 7.4$ at $37^{\circ} \mathrm{C}$ (closed circles) and $4^{\circ} \mathrm{C}$ (open circles). The concentration of lutein was determined using an HPLC system. Each point represents the mean with S.D. of 3-9 measurements.

\section{Effects of ATP-depleting conditions on the} permeation of lutein across Caco-2 cells

We also investigated the effect of energy-dependent transporters to lutein permeation in the intestine with the same condition described previously (24). The buffer was preincubated at $37^{\circ} \mathrm{C}$ for $10 \mathrm{~min}$ in the presence of $10 \mathrm{mM}$ sodium fluoride and $10 \mathrm{mM}$ sodium azide (they are inhibitors of ATPase in mitochondrial cytochrome. Then the permeation of lutein by Caco- 2 cells in the presence these inhibitors was investigated. Similarly, typical ATP-depleting compound, the effect of $50 \mu \mathrm{M}$
CCCP (carbonyl cyanide m-chlorophenylhydrazone) which is an inhibitor of oxidative phosphorylation was also investigated with the almost same condition described previously (28). The permeation of lutein by Caco-2 cells did not change significantly.

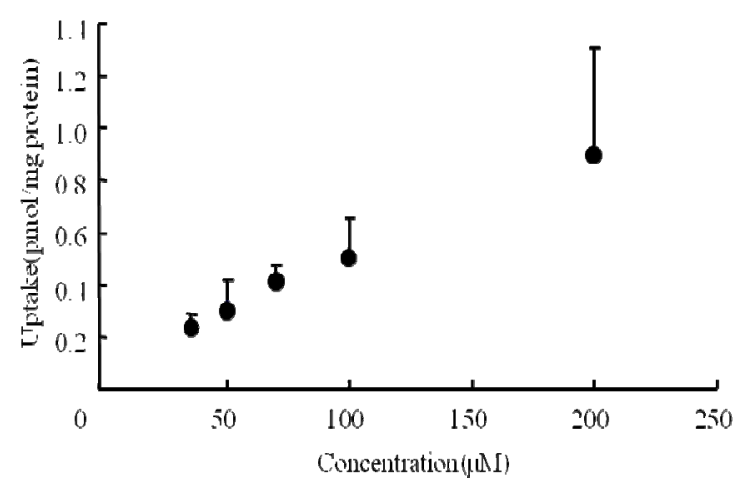

Figure 3. Concentration-dependence of the accumulation of lutein by Caco-2 cells. The accumulation of lutein $(10-200 \mu \mathrm{M})$ was measured at $\mathrm{pH}$ 7.4 at $37^{\circ} \mathrm{C}$. The concentration of lutein was determined using an HPLC system. Each point represents the mean with S.D. of 3-5 measurements.

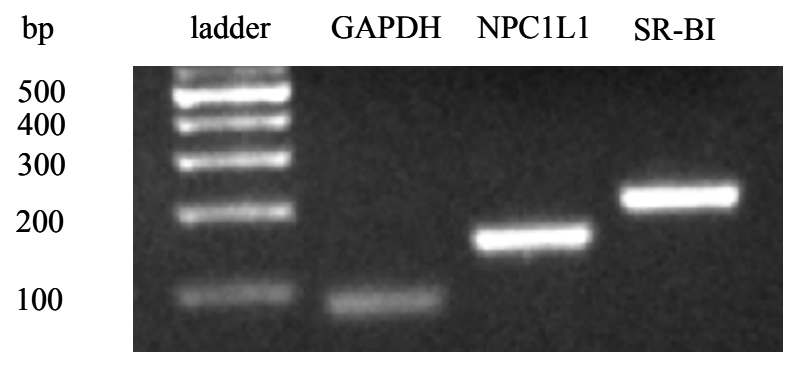

Figure 4. Expression of NPC1L1 and SR-BI in Caco-2 cells. RT-PCR was performed with total RNA isolated from Caco- 2 cells. This data is the typical result from 3 independent experiments.

\section{DISCUSSION}

Lutein has received much attention due to its powerful antioxidant activity. Since humans cannot synthesize lutein de novo, it must be digested as food. However, there is little information on the detailed absorption mechanism of lutein. The physiological importance of an orally administered compound depends on its interaction with target tissues. A specific absorption mechanism of lutein has been reported, but its selective inhibitors did not inhibit the lutein accumulation completely (12). 


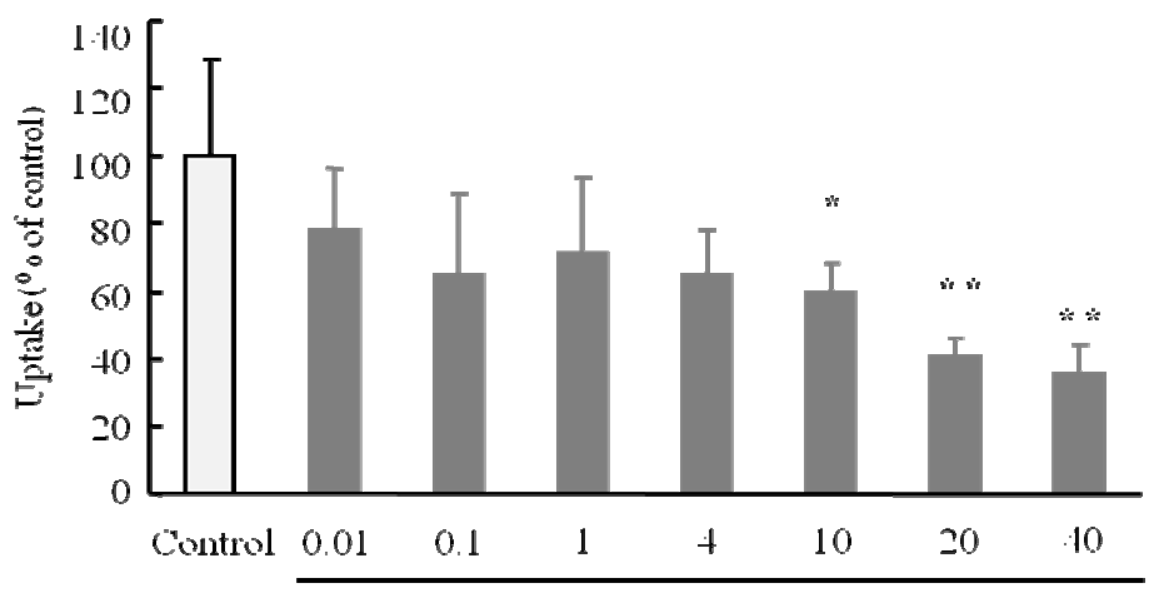

Ezetimibe $(\mu \mathrm{M})$

Figure 5-A. Inhibitory effect of ezetimibe on the accumulation of lutein in Caco-2 cells. The accumulation of lutein (35 $\mu \mathrm{M}$ ) was measured at $\mathrm{pH} 7.4$ at $37^{\circ} \mathrm{C}$ in HBSS in the presence and absence (control) of ezetimibe. The concentration of lutein was determined using an HPLC system. Each column represents the mean with S.D. of 5-9 measurements. *; significantly different from control at $\mathrm{p}<0.05, * * ; \mathrm{p}<0.01$

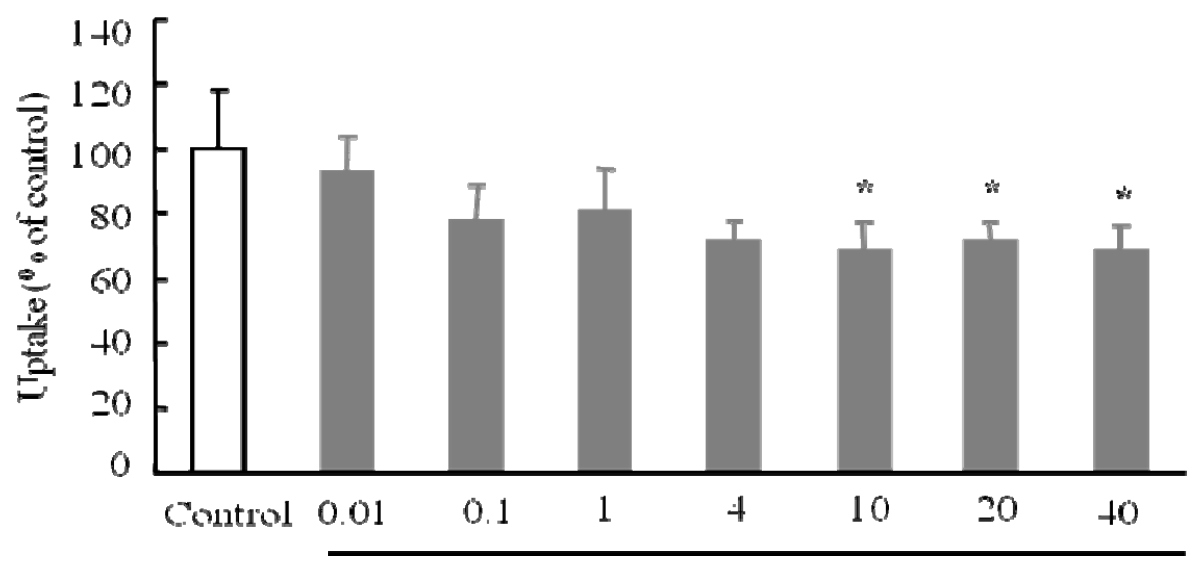

BLT-I ( $\mu \mathrm{A} I)$

Figure 5-B. Inhibitory effect of BLT-1 on the accumulation of lutein in Caco-2 cells. The accumulation of lutein (35 $\mu \mathrm{M}$ ) was measured at $\mathrm{pH} 7.4$ at $37^{\circ} \mathrm{C}$ in HBSS in the presence and absence (control) of BLT-1 (block lipid transport-1). The concentration of lutein was determined using an HPLC system. Each column represents the mean with S.D. of 4-6 measurements. *; significantly different from control at $\mathrm{p}<0.05$

We hypothesized another absorption mechanism of lutein and we investigated in detail the absorption mechanism of lutein in the intestine. The involvement of the candidate transporter NPC1L1 in lutein accumulation by the apical side of enterocytes was studied using Caco-2 cell monolayers as a model of the human intestinal epithelium. NPC1L1 is enriched in the apical membrane of the small intestine and mediates intestinal cholesterol absorption (29). Ezetimibe binds specifically to NPC1L1 and inhibits
NPC1L1-mediated accumulation (30). In this study, we demonstrated that the lutein accumulation by Caco-2 cells was significantly decreased by ezetimibe (Figure 5-A). Cholesterol was shown to directly bind to SSD and to be transported across enterocytes, but ezetimibe inhibited the lutein accumulation in this study, though lutein does not have a sterol structure. NPC1L1 overexpression appears to facilitate the accumulation of vitamin E, which does not have a sterol structure, in an ezetimibe-sensitive manner (21). Vitamin E 
transport is also partly mediated by SR-B1 (17). In this study, we confirmed that the lutein accumulation by Caco-2 cells was significantly decreased in a BLT-1-sensitive manner (Figure 5-B). This result is consistent with results of a previous study (12). SR-B1 is a lipoprotein receptor that is highly expressed in the apical side of the small intestine. The involvement of this membrane transporter is not surprising since SR-B1 seems to have low substrate specificity, mediating the transport of many lipophilic substrates $(17,22,31$, 32). Intestinal absorption of lycopene, a carotenoid mainly contained in tomatoes, involves SR-B1 but not NPC1L1 (33). These mechanisms may involve a passive diffusion or another apical membrane transporter. At this time, we consider that other mechanisms such as passive diffusion or other membrane transporters such as ABCA1 except for NPC1L1 or SR-B1 may be involved in the intestinal uptake of lutein since it is a highly lipophilic compound classified into carotenoids. These results obtained for lutein in this study are remarkable, but detailed mechanisms such as substrate specificity of NPC1L1 and accumulation of these compounds have not been elucidated. Further studies are needed to determine whether an intestinal cholesterol transporter influences the absorption of lipophilic compounds such as lutein.

We also hypothesized the involvement of efflux transporters in the intestine because lutein showed very low bioavailability. Therefore, to clarify the possible contribution of energy-dependent transporters to lutein transport in the intestine, the effects of ATP-depleting regents were investigated. The permeation of lutein by Caco-2 cells was not changed significantly in an ATP-depleted condition using regents such as sodium fluoride, sodium azide and CCCP (Figure 6). We also confirmed the mRNA expression of efflux transporters, P-gp (P-glycoprotein), MRP2 (multidrug resistance-associated protein 2) and BCRP (breast cancer-resistance protein), in Caco-2 cells by RT-PCR (data not shown). We consider that these efflux transporters would not contribute largely to the intestinal absorption of lutein since the permeation of lutein across Caco-2 cells did not change significantly as shown in Figure 6.

In a clinical setting, patients usually take many kinds of drugs at the same time. Drug-drug interactions involving drugs having a narrow therapeutic range might have serious adverse consequences. Food-drug interactions also would increase the risk of adverse events. For example, Zetia $^{\circledR}$ is ezetimibe and a widely used medicine for hyperlipidemia. In patients with hyperlipidemia who take ezetimibe, there might be little effect of lutein for prevention of AMD. They would need to pay attention to the timing of these drugs or foods including supplements. In any case, it is important to be aware of the potential of lutein-drug interaction and to act in order to prevent undesirable and harmful clinical consequences. Further investigations are needed to obtain clinical evidence of more efficient use of lutein.

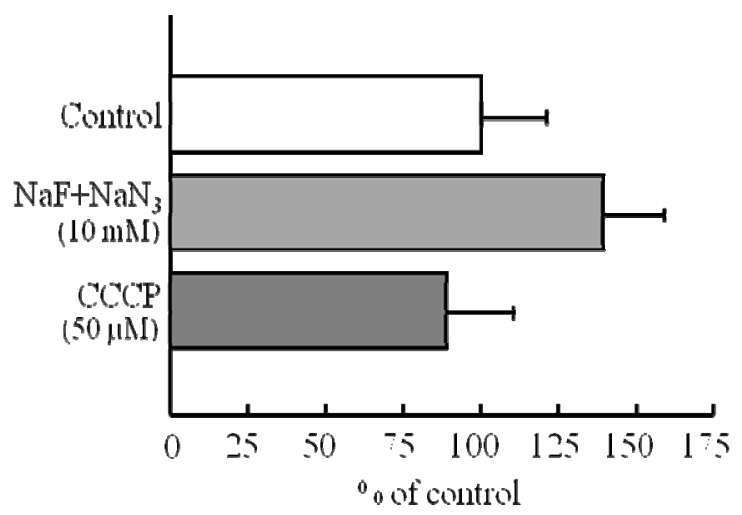

Figure 6. Effects of ATP-depleting conditions on the permeation of lutein across Caco- 2 cells. The buffer was preincubated at $37^{\circ} \mathrm{C}$ for $10 \mathrm{~min}$ in the presence of 10 $\mathrm{mM}$ sodium fluoride and $10 \mathrm{mM}$ sodium azide or $50 \mu \mathrm{M}$ CCCP or HBSS (control). And the permeation of lutein in the presence of these inhibitors was investigated. The permeation of lutein $(35 \mu \mathrm{M})$ for 60 min was measured at $\mathrm{pH} 7.4$ at $37^{\circ} \mathrm{C}$ in $\mathrm{HBSS}$ in the presence and absence (control) of ATP-depleting compounds. The concentration of lutein was determined using an HPLC system. Each column represents the mean with S.D. of 3 measurements.

\section{CONCLUSIONS}

We have demonstrated the involvement of NPC1L1 and SR-B1 in the absorption of lutein in the intestine. The results show that lutein absorption is, at least in part, mediated by influx transporters NPC1L1 and SR-B1 rather than mediated by efflux transporters such as ABC (ATP-binding cassette) transporters.

\section{ACKNOWLEDGEMENT.}

We thank JARD Inc. and Koyo Mercantile Co., Ltd 
for providing lutein. This work was supported in part by Kuribayashi Foundation, Urakami Foundation for Food and Food Culture Promotion, The Akiyama Life Science Foundation and Grant-in-Aid for Young Scientists (A) Research from the Ministry of Education, Culture, Sports, Science and Technology, Japan.

\section{REFERENCES}

1. Granado F, Olmedilla B, Blanco I, Rojas-Hidalgo E. Major fruit and vegetable contributors to the main serum carotenoids in the Spanish diet. Eur J Clin Nutr, 1996; 50:246-250.

2. Sommerberg O, Keunen JE, Bird AC, van Kuijk FJ. Fruits and vegetables that are source for lutein and zeaxanthin: the macular pigment in human eyes. $\mathrm{Br}$ J Ophthalmol, 1998; 82:907-910.

3. Granado F, Olmedilla B, Blanco I. Nutritional and clinical relevance of lutein in human health. $\mathrm{Br} \mathrm{J}$ Nutr, 2003; 90:487-502.

4. Bone RA, Landrum JT, Friedes LM, Gomez CM, Kilburn MD, Menendez E, Vidal I, Wang W. Distribution of lutein and zeaxanthin stereoisomers in the human retina. Exp Eye Res, 1997; 64:211-218.

5. Krinsky NI, Landrum JT, Bone RA. Biologic mechanisms of the protective role of lutein and zeaxanthin in the eye. Annu Rev Nutr, 2003; 23:171-201.

6. Beatty S, Boulton M, Henson D, Koh HH, Murray IJ. Macular pigment and age related macular degeneration. Br J Ophthalmol, 1999; 83:867-877.

7. Broekmans WM, Berendschot TT, Klöpping-Ketelaas IA, de Vries AJ, Goldbohm RA, Tijburg LB, Kardinaal AF, van Poppel G. Macular pigment density in relation to serum and adipose tissue concentrations of lutein and serum concentrations of zeaxanthin. Am J Clin Nutr, 2002; 76:595-603.

8. Moeller SM, Parekh N, Tinker L, Ritenbaugh C, Blodi B, Wallace RB, Mares JA. Association between intermediate aged-related macular degeneration and lutein and zeaxanthin in the carotenoids in aged related eye disease study. Arch Ophthalmol, 2006; 124:1151-1162.

9. Fine SL, Berger JW, Maguire MG, Ho AC. Age-related macular degeneration. N Engl J Med, 2000; 342:483-492.

10. Miyazaki M, Kiyohara Y, Yoshida A, Iida M, Nose Y, Ishibashi T. The 5-year incidence and risk factors for age-related maculopathy in a general Japanese population: the Hisayama study. Invest Opthalmol Vis Sci, 2005; 46:1907-1910.

11. Izumi-Nagai K, Nagai N, Ohgami K, Satofuka S, Ozawa Y, Tsubota K, Umezawa K, Ohno S, Ishida S.
Macular pigment lutein is anti-inflammatory in preventing choroidal neovascularization. Arterioscler Thromb Vasc Biol, 2007; 27:2555-2565.

12. Reboul E, Abou L, Mikail C, Ghiringhelli O, André M, Portugal H, Jourdheuil-Rahmani D, Amiot MJ, Lairon D, Borel P. Lutein transport by Caco-2 TC-7 cells occurs partly by a facilitated process involving the scavenger receptor class B type I (SR-BI). Biochem J, 2005; 387:455-461.

13. Cai SF, Kirby RJ, Howles PN, Hui DY. Differentiation-dependent expression and localization of the class B type I scavenger receptor in intestine. J Lipid Res, 2001; 42:902-909.

14. Cai L, Eckhardt ER, Shi W, Zhao Z, Nasser M, de Villiers WJ, van der Westhuyzen DR. Scavenger receptor class $B$ type I reduces cholesterol absorption in cultured enterocyte CaCo- 2 cells. J Lipid Res, 2004; 45:253-262.

15. Werder M, Han CH, Wehrli E, Bimmler D, Schulthess G, Hauser H. Role of scavenger receptors SR-BI and CD36 in selective sterol uptake in the small intestine. Biochemistry, 2001; 40:11643-11650.

16. Raldúa D, Babin PJ. BLT-1, a selective inhibitor of the HDL receptor SR-BI, induces a copper-dependent phenotype during zebrafish development. Toxicol Lett, 2007; 175:1-7.

17. Reboul E, Klein A, Bietrix F, Gleize B, Malezet-Desmoulins C, Schneider M, Margotat A, Lagrost L, Collet X, Borel P. Scavenger receptor class B type I (SR-BI) is involved in vitamin E transport across the enterocyte. J Biol Chem, 2006; 281:4739-4745.

18. Altmann SW, Davis HR, Zhu Li-ji, Yao X, Hoos LM, Tetzloff G, Lyer SP, Maguire M, Golovko A, Zeng M, Wang L, Murgolo N, Graziano MP. Neimann-Pick C1 Like 1 Protein is critical for intestinal cholesterol absorption. Science, 2004; 303:1201-1204.

19. Sané AT, Sinnett D, Delvin E, Bendayan M, Marcil V, Ménard D, Beaulieu JF, Levy E. Localization and role of NPC1L1 in cholesterol absorption in human intestine. J Lipid Res, 2006; 47:2112-2120.

20. $\mathrm{Yu} \mathrm{L}$, The structure and function of Neimann-Pick C1-Like 1 protein. Curr Opin Lipidol, 2008; 19:263-269.

21. Narushima K, Takada T, Yamanashi Y, Suzuki H. Neimann-Pick C1-Like 1 mediates $\alpha$-tocopherol transport. Mol Pharmacol, 2008; 74: 42-49.

22. Duong M, Collins HL, Jin W, Zanotti I, Favari E, Rothblat GH. Relative contributions of ABCA1 and SR-BI to cholesterol efflux to serum from fibroblasts and macrophages. Arterioscler Thromb Vasc Biol, 2006; 26:541-547.

23. Itagaki S, Kobayashi Y, Otsuka Y, Kubo S, 
Kobayashi M, Hirano T, Iseki K. Food-drug interaction between ferulic acid and nateglinide involving the fluorescein $/ \mathrm{H}^{+}$cotransport system. J Agric Food Chem, 2005; 53:2499-2502.

24. Itagaki S, Ochiai A, Kobayashi M, Sugawara M, Hirano $\mathrm{T}$, Iseki $\mathrm{K}$. Interaction of coenzyme Q10 with the intestinal drug transport P-glycoprotein. J Agric Food Chem, 2008; 56:6923-6927.

25. Sato Y, Kobayashi M, Itagaki S, Hirano T, Noda T, Mizuno S, Sugawara M, Iseki K. Pharmacokinetic properties of lutein emulsion after oral administration to rats and effect of food intake on plasma concentration of lutein. Biopharm Drug Dispos, in press

26. Lowry OH, Rosebrough NJ, Farr AL, Randall RJ. Protein measurement with the folin phenol reagent. J Biol Chem, 1951; 193:265-275.

27. Chisaki I, Kobayashi M, Itagaki S, Hirano T, Iseki K. Liver X receptor regulates expression of MRP2 but not that of MDR1 and BCRP in the liver. Biochim Biophys Acta, 2009; 1788:2396-2403.
28. Goto Y, Itagaki S, Umeda S, Kobayashi M, Hirano T, Iseki K, Tadano K. Transepitherial transport of telmisartan in Caco-2 monolayers. Biol Pharm Bull, 2005; 28:2235-2239.

29. Betters JL, Yu L. NPC1L1 and cholesterol transport. FEBS Lett, 2010; 584:2740-2747.

30. Davis HR, Altmann SW. Neimann-Pick C1 Like 1 (NPC1L1) and intestinal sterol transporter. Biochim Biophys Acta, 2009; 1791:679-683.

31. Davis HR, Basso F, Hoos LM, Tetzoloff G, Lally SM, Altmann SW. Cholesterol homeostasis by the intestine: Lessons from Niemann-Pick C1 Like 1 [NPC1L1]). Atheroscler Suppl, 2008; 9: 77-81.

32. During A, Harrison EH. Mechanisms of provitamin A (carotenoid) and vitamin A (retinol) transport into and out of intestinal Caco-2 cells. J Lipid Res, 2007; 48:2283-2294.

33. Moussa M, Landrier JF, Reboul E, Ghiringhelli O, Coméra C, Collet X, Fröhlich K, Böhm V, Borel P. Lycopene absorption in human intestinal cells and in mice involves scavenger receptor class B type I but not Nemann-Pick C1-Like 1. J Nutr, 2008; 138:1432-1436. 